\title{
LEARNERS' PERCEPTION AND PRACTICES ON AUTONOMOUS LANGUAGE LEARNING IN EFL SETTINGS
}

\author{
Maya Marsevani \\ English Language Education, Universitas Internasional Batam \\ e-mail:maya@uib.ac.id
}

\begin{abstract}
This research was aimed to investigate learners' perception and practices of understanding teachers' teaching objectives and requirements related to autonomous language learning, setting up their objectives and study plans to autonomous language learning, and find out learners perceive in learning English autonomously. To gain a deep understanding and utilizing the objectives, the researcher employed descriptive qualitative research. The research findings were extracted through both an online questionnaire and interview. Some constraints were reported in this research, but more positive responses were still shown by the learners. They positively disposed to the notion of learner autonomy. The learners specifically showed positive attitudes toward instructors' teaching objectives and requirements, setting up their objectives and study plans, and their practices in learning English autonomously. Further researchers, thus, need to research in various universities with a large number to gain a deeper and wider understanding about learners perceive in autonomous language learning.
\end{abstract}

Keywords: learner autonomy, language learning, perceptions, practices

\section{INTRODUCTION}

By increasing attention given to learner autonomy, it has challenged researchers to contribute and conduct research within the field of learner autonomy. There is no doubt that learner autonomy becomes one of the key elements in language learning success where self-directed learning, learner-centered, and self-managed learning are highlighted (Amirian, 2017). It offers a foundational platform to engage in further lifelong learning opportunities.

The most quoted definition is given by Holec as citied in Ahmadzadeh, R., Zabardast (2014), he states that learner autonomy is the ability to take charge of one's learning where the learner is capable of determining the objectives, defining the contents and progression, selecting methods or techniques that will be used and able to monitor and evaluate what has been acquired as well. It is in line with some studies (Boyce, 2010; Joshi, 1970; Le, 2013) that define learner has a good chance to learn English autonomously.

Knowing the importance of autonomy level and the impact of autonomy on learning, learners should have extra efforts to inquire what, how, and why it is learned. Learners should also be trained to be autonomous in learning English by using appropriate strategies (Lengkanawati, 2017). By implementing appropriate strategies, they will have great potency in selecting and adapting their learning strategies and styles. It makes them as well capable to improve their learning by themselves. Hence, learners should become the center of attention and a major concern in language classrooms. However, some of them still had a lack of awareness in learning English and a lack of autonomous learning experience. In real practice, they involved fewer 
effort and still not independent in learning English. For example, they did not take advantage of learning English beyond the classroom from available resources such as attending seminars or conferences, talking to the teachers or friends outside the classroom, and developing their skills through audio-visual materials.

Moreover, the experts signify the notion of learner autonomy refers to selfevident in which the students learn independently, and taking charge, but this term does not refer to those definitions. As Little (1991), cited in Benson, 2008 emphasizes the term of autonomy is not a self-instruction. it does not mean the students learn without a teacher or do not require a teacher's responsibility to get on with things as best they can. In other words, the phrase of autonomy is not just to the learner as is often the case and the teacher's role is essential to develop autonomous learning.

The learners further need teachers' instructions to guide them in learning English. In other words, it will be useful for learners and teachers to take into consideration in teaching and learning process. As Vieira (2007) and Benson (2008) point out that one of the ways to develop learner autonomy is teachers have to foster their awareness in learning English. In other words, the teacher's role is essential for learner autonomy. Vieira also adds the teachers have systematically been kept backstage to promote learner autonomy. The teacher should support learners to learn autonomously and raise their awareness by creating a good atmosphere in the learning process (Salimi, A., \& Ansari, 2015). It means that teachers should have autonomous skills and experience autonomy-oriented training to foster learners and create a good atmosphere in the classroom. It makes learners able to take a positive stance in learning development and take charge of their own learning by following the models of their teachers.

In fact, one of the reasons learners had a lack of motivation and awareness in learning English because instructional activities are given by the teachers somehow did not meet learners' needs and interests that caused learners' boredom in classroom activities. Although some teachers desired to implement learner autonomy in EFL classrooms, several factors should be considered such as limited time allotted for English subjects and a wide range of learners' abilities.

Previous research about learner autonomy was conducted by Le (2013). She conducted research by using a teacher-guided/learner-decided approach to promote learner autonomy. Her study was to investigate how students' and teachers' awareness of learner autonomy and the perceptions of their roles in English language learning affect their beliefs and practice in promoting greater autonomy in the context of tertiary education in Vietnam. In line with Le, Boyce (2010) also assessed the current strategy practices of a group of English language learners, the intention being to increase learners' awareness of their strategy usage and help them identify future learning opportunities. Both researches implemented strategies to foster learner autonomy.

In Indonesia context, learner autonomy had been conducted. Kemala (2016) analyzed the factors influencing learners in learning English autonomously. She found five factors influenced learner autonomy; motivation, social environment, tasks, teachers, and materials. Another research about learner autonomy in Indonesian EFL settings was conducted by Mardjuki (2018). He found that there was no gender-based discrepancy among EFL Indonesian Learners. Every autonomous learner has a personal preference to deal with encountered challenges in EFL classrooms. 
Some studies on learner autonomy either in Indonesia or other countries had been carried out. However, the researcher did not a study with a special reference to Indonesia context about learners' perception and practices on autonomous language learning that focus on understanding teachers' teaching objectives and requirements related to autonomous language learning, setting up their objectives and study plans to autonomous language learning and find out learners' practices in learning English autonomously. In essence, perception is one of the key components for analyzing learners' situation and feeling. It is not something that should be taken for granted, it cannot be bound and limited. In other words, perception is such an important aspect of learners that can be good energy sources to give information and fulfill leaners' ambition. The art of perception further ease them to grasp the issues or circumstances far higher than objective approach.

Hence, the researcher was interested to investigate the autonomous activities of the learners in learning English which only focuses on exploring their activities in their own learning in class and beyond the class by addressing the following questions: (1) What are learners' perception of understanding teachers' teaching objectives and requirements related to autonomous language learning?; (2) What are learners' perception of setting up their learning objectives and study plans for autonomous language learning?; (3) How do learners perceive autonomous language learning?

\section{METHOD}

The researcher carried out descriptive qualitative research to explore students' perceptions concerning learner autonomy. According to Malik and Hamied (2014), qualitative research focuses on gaining a rich and complex understanding of a specific social context or phenomenon. For this reason, it is suitable to gain a deep understanding of the topic being discussed. Moreover, a descriptive method was used because the data of this research was presented descriptively, and it described and interpreted the objects naturally. As Ary, Jacobs, Sorensen, and Razavieh (2010) state the purpose of a descriptive qualitative method is to study a phenomenon, a process, or a particular point of view intensely and naturally and gain a wide and deep understanding of a researcher's specific question.

This research took place in a private University in Batam. This University was chosen because the researcher had accessibility, and the respondents were familiar with learner autonomy. The data was collected in December 2020. Specifically, the respondents of this research were two English classes with the total 64 learners. The learners were the first year that came from various departments. The researcher used online questionnaire and online interview to collect the data. Besides Covid-19 pandemic, it was more reliable than face to face surveys. Other opportunities using online survey tools had offered as well such as response speed and rate, and variable costs.

According to Creswell (2012), the questionnaire can be used as an instrument to conduct case study qualitative research. Hence, this research used the questionnaire as the main data. The type of questionnaire was a close-ended questionnaire where responses are limited to the stated alternatives and respondent cannot express his or her judgment (Fraenkel \& Wallen, 2008). The researcher used this kind of questionnaire for several reasons; it administered quickly, it was easy of doing the preliminary analysis and it also provided a specific answer. 
The questionnaire was adapted from Genç (2015) and Misır, Koç, and Koç (2018). There are 35 closed items questions that related to the problems. The closeended questionnaire was used to gain students' perceptions of learner autonomy in language learning. The researcher used google form as an online survey. The google form was designed and developed as web-based questionnaires. This google form was distributed online and 64 learners responded the form.

In the midst of the COVID-19 pandemic, a series of online interviews was carried out with five learners who were chosen randomly by the researcher. The researcher made the schedule for the respondents because they had different availability in conducting an online interview. The platform used in this research was Microsoft Teams since the researcher and the respondents were familiar with this platform. Moreover, the purpose behind this interview was to complement the qualitative data through gathering additional information about learners' views of their understanding instructors' teaching objectives and requirements related to autonomous language learning, setting up their learning objectives and study plans to autonomous language learning, and monitoring and evaluating the English learning process. An interview is defined as a way where a researcher and the participants take part in a discourse concerned with some questions connected with the focus of the research (DeMarrais, 2004).

The researcher used English and Bahasa Indonesia to interview the participants to make the interview ran better. participants further had the chance to express their thought without having to be limited by a language barrier. In addition, the transcriptions were translated into English after conducting the interview.

\section{FINDINGS AND DISCUSSIONS}

The first section of the questionnaire assessed learners' view of understanding instructors' teaching objectives and requirements in learning English. Analysis of the data shows their learning movement was more autonomous. The results pointed out that most of the learners tended to concern their teachers' teaching objectives and requirements in learning English. All the items had high response with the percentages of $92 \%, 80 \%, 80 \%, 70 \%, 87 \%, 92 \%$ respectively. In addition, item 1 and item 6 had the highest response that indicated learners knew learning English was very important and the teacher would use a certain class activity to improve their skills. As Zhenhui (2002) states that matching a certain class activity can only be done effectively when teachers are aware of students' needs and capacities. It might have positive consequences if the teacher was able to select, adapt, and deliver an appropriate classroom activity. An appropriate activity can be media to improve learners' skills and decrease their anxiety and boredom (Samperio Sanchez, 2017). The specific result can be seen below.

Table 1. Learners' View of Understanding Teachers' Teaching Objectives and Requirements in Learning English

\begin{tabular}{|c|c|c|c|c|c|c|c|c|c|c|c|}
\hline \multirow{2}{*}{ No. } & \multirow{2}{*}{ Statements } & \multicolumn{2}{|l|}{ SD } & \multicolumn{2}{|l|}{ D } & \multicolumn{2}{|l|}{$\mathbf{A}$} & \multicolumn{2}{|l|}{$\mathbf{S A}$} & \multirow{2}{*}{ Mean } & \multirow{2}{*}{ STD } \\
\hline & & TV & $\mathbf{P}$ & TV & $\mathbf{P}$ & TV & $\mathbf{P}$ & TV & $\mathbf{P}$ & & \\
\hline 1 & $\begin{array}{l}\text { I truly understand the } \\
\text { objectives of the } \\
\text { teacher uses a certain } \\
\text { class activity to } \\
\text { improve my skills }\end{array}$ & 1 & $2 \%$ & 4 & $6 \%$ & 37 & $58 \%$ & 22 & $34 \%$ & 3.25 & 0.642 \\
\hline
\end{tabular}




\begin{tabular}{|c|c|c|c|c|c|c|c|c|c|c|c|}
\hline \multirow{2}{*}{ No. } & \multirow{2}{*}{ Statements } & \multicolumn{2}{|l|}{ SD } & \multicolumn{2}{|l|}{ D } & \multicolumn{2}{|l|}{$\mathbf{A}$} & \multicolumn{2}{|l|}{$\mathbf{S A}$} & \multirow{2}{*}{ Mean } & \multirow{2}{*}{ STD } \\
\hline & & TV & $\mathbf{P}$ & TV & $\mathbf{P}$ & TV & $\mathbf{P}$ & TV & $\mathbf{P}$ & & \\
\hline 2 & $\begin{array}{l}\text { I know how to keep up } \\
\text { with the progress of the } \\
\text { course with teacher's } \\
\text { guidance }\end{array}$ & 1 & $2 \%$ & 12 & $19 \%$ & 35 & $55 \%$ & 16 & $25 \%$ & 3.03 & 0.712 \\
\hline 3 & $\begin{array}{l}\text { I learn English well by } \\
\text { following teacher's } \\
\text { instruction }\end{array}$ & 0 & $0 \%$ & 13 & $20 \%$ & 35 & $55 \%$ & 16 & $25 \%$ & 3.05 & 0.677 \\
\hline 4 & $\begin{array}{l}\text { I turn the teacher's } \\
\text { teaching objectives into } \\
\text { my own learning } \\
\text { objectives }\end{array}$ & 1 & $2 \%$ & 18 & $28 \%$ & 36 & $56 \%$ & 9 & $14 \%$ & 2.83 & 0.680 \\
\hline 5 & $\begin{array}{l}\text { I understand the course } \\
\text { requirements and the } \\
\text { class requirements }\end{array}$ & 0 & $0 \%$ & 8 & $13 \%$ & 43 & $67 \%$ & 13 & $20 \%$ & 3.08 & 0.572 \\
\hline 6 & $\begin{array}{l}\text { I understand why I } \\
\text { should study hard } \\
\text { according to the course } \\
\text { objectives }\end{array}$ & 0 & $0 \%$ & 5 & $8 \%$ & 29 & $45 \%$ & 30 & $47 \%$ & 3.39 & 0.633 \\
\hline
\end{tabular}

The follow-up interviews with five respondents further helped the researcher to gain a deeper understanding of the underlying reasons behind the results of the questionnaire. Throughout the interview session, most of the respondents pointed out that they still needed the teacher's guidance to help them in learning English. It very significant that the teacher should not only complete teaching a lesson but also plan teaching techniques and guide the learners to improve and master their language (Kumbakonam et al., 2017).

Learner 1: "I personally still need teacher's instruction and guidance because I will spend much time to learn English by myself."

Learner 2: "If I read some materials, I will not directly catch the point, I should read many times to understand it. But, with the teacher's explanation and direction, it eases me to understand it."

Moreover, they are concerned with the teacher's class activity in the teaching and learning process. They agreed that it was important to improve students' skills in learning English. It would help them as well to find out their strategies or styles in learning English.

Learner 2: "[...] Yes, because every student has different learning strategies, every class has a different treatment. Some of us better use visual learning and the rest somehow easy to understand with audio-visual. So, it is important for teachers to implement certain class activity to improve students' skills."

Learner 3: Using certain class activities can attract students in learning English. Attractive learning materials will directly increase students' motivation."

The second section of the questionnaire shows a medium satisfactory level of learning autonomy in setting up personal learning objectives and study plans. More than $50 \%$ of respondents agreed on items 7,8 , and 9 . The responses to item 7 prove that 32 learners made their own English study plan. Among them, $78 \%$ could make their own study objectives according to their own situations. The mean value of 2.98 clearly marked that the learners adjusted their study plan if necessary. However, most the learners tended to have an unsatisfactory level of autonomy in three items. The averages of these items were below 2.50. The responses for item 11 showed that $57 \%$ of them 
disagreed with setting up their English study objectives according to the English Syllabus. The other lowest mean values are on item 10 and 12. The responses of these items underlined that they did not make a time plan to study English and they did not make good use of their free time in studying English as well (See table 3).

Table 2. Learners' View of Setting Up Their Learning Objectives and Study Plans to Autonomous Language Learning

\begin{tabular}{|c|c|c|c|c|c|c|c|c|c|c|c|}
\hline \multirow{2}{*}{ No. } & \multirow{2}{*}{ Statements } & \multicolumn{2}{|l|}{ SD } & \multicolumn{2}{|l|}{ D } & \multicolumn{2}{|l|}{$\mathbf{A}$} & \multicolumn{2}{|l|}{$\mathbf{S A}$} & \multirow{2}{*}{ Mean } & \multirow{2}{*}{ STD } \\
\hline & & TV & $\mathbf{P}$ & TV & $\mathbf{P}$ & TV & $\mathbf{P}$ & TV & $\mathbf{P}$ & & \\
\hline 7 & $\begin{array}{l}\text { Besides the class } \\
\text { tasks } \\
\text { assignments, I will } \\
\text { make my own } \\
\text { English study plan }\end{array}$ & 3 & $5 \%$ & 29 & $45 \%$ & 22 & $34 \%$ & 10 & $16 \%$ & 2.61 & 0.809 \\
\hline 8 & $\begin{array}{l}\text { I make my own } \\
\text { study objectives } \\
\text { according to my } \\
\text { own situation }\end{array}$ & 0 & $0 \%$ & 14 & $22 \%$ & 36 & $56 \%$ & 14 & $22 \%$ & 3.00 & 0.667 \\
\hline 9 & $\begin{array}{l}\text { I adjust my study } \\
\text { plan if necessary }\end{array}$ & 4 & $6 \%$ & 15 & $23 \%$ & 23 & $36 \%$ & 22 & $34 \%$ & 2.98 & 0.917 \\
\hline 10 & $\begin{array}{l}\text { I make a time plan } \\
\text { to study English }\end{array}$ & 8 & $13 \%$ & 29 & $45 \%$ & 21 & $33 \%$ & 6 & $9 \%$ & 2.39 & 0.828 \\
\hline 11 & $\begin{array}{l}\text { I set up my English } \\
\text { study objectives } \\
\text { according to the } \\
\text { English Syllabus }\end{array}$ & 6 & $9 \%$ & 31 & $48 \%$ & 24 & $38 \%$ & 3 & $5 \%$ & 2.38 & 0.724 \\
\hline 12 & $\begin{array}{l}\text { I make good use of } \\
\text { my free time in } \\
\text { studying English }\end{array}$ & 9 & $14 \%$ & 28 & $44 \%$ & 20 & $31 \%$ & 7 & $11 \%$ & 2.39 & 0.866 \\
\hline
\end{tabular}

Teachers somehow adopted a spoon-feeding and traditional teaching style that made learners adjusted the learning materials according to his/her situation. In contrast with the data from the questionnaire, the follow-up interviewers said that they learned English with media or use their free time to increase their skills in English. It means that they had good time management in learning English in the classroom and beyond the class. Moreover, they claim it helps them to achieve good output results. It is in line with Green and Skinner (2005) that better time management can be proved as a good predictor of other factors which gives great attention to enhance learners' productivities and enable them to learn in smarter ways that affect higher outcomes.

Learner 1: "I learn English every day, in the classroom and out-of-class. I always learn through media such as a movie, song lyrics, CNN news, and many more. It works for me to improve my English skill. After got new vocabularies, I usually use them in my daily life, I use those vocabularies to practice with my friends."

Learner 4: "[...] I am responsible with my own study objectives because I obviously know my strengths and weaknesses in learning English. I also have good time management in learning English because I usually set my time to learn English at home. It works for me to improve my English skills and achieve a better score."

Learner 5: "[...] I usually adjust my study plan because the learning process at school sometimes is not appropriate with my learning styles. I will use my own strategies to 
understand some materials. By fitting my own strategies, I achieve a good score in English."

Moreover, in terms of learners' awareness, there was an item that has the highest percentage (item 16). The mean was 3.39 that shows $88 \%$ of the learners used the internet and computers to study and improve English. Other highest responses in selfmonitoring and evaluation were item 30 , item 31 , and item 32 . The responses to these items indicated that almost $85 \%$ of respondents had good monitoring and evaluation in learning English. On the other hand, some students had negative attitudes toward selfefforts. It can be seen from three items that had low mean values in self-effort. Item 21 clearly pointed out as the lowest percentage. 16 out of 64 agreed that the learners attended different seminars, training courses, conferences to improve their English. Meanwhile, most the learners show negative attitudes on item 15 and item 22. Almost $70 \%$ of the learners spoke unconfidently in front of the people and they rarely talk to the teachers and friends outside the course in English (See table 4).

Table 3. Learners' Practices in Autonomous Language Learning

\begin{tabular}{|c|c|c|c|c|c|c|c|c|c|c|c|}
\hline \multirow{2}{*}{ No. } & \multirow{2}{*}{ Statements } & \multicolumn{2}{|l|}{ SD } & \multicolumn{2}{|l|}{ D } & \multicolumn{2}{|l|}{$\mathbf{A}$} & \multicolumn{2}{|l|}{ SA } & \multirow{2}{*}{ Mean } & \multirow{2}{*}{ STD } \\
\hline & & TV & $\mathbf{P}$ & TV & $\mathbf{P}$ & TV & $\mathbf{P}$ & TV & $\mathbf{P}$ & & \\
\hline 13 & $\begin{array}{l}\text { I preview before the } \\
\text { course (i.e. see } \\
\text { summary, lessons } \\
\text { etc.) }\end{array}$ & 8 & $13 \%$ & 20 & $31 \%$ & 29 & $45 \%$ & 7 & $11 \%$ & 2.55 & 0.853 \\
\hline 14 & $\begin{array}{l}\text { I use strategies when } \\
\text { I practice my } \\
\text { listening skills, oral } \\
\text { English, English } \\
\text { reading and when I } \\
\text { write in English }\end{array}$ & 8 & $13 \%$ & 15 & $23 \%$ & 31 & $48 \%$ & 10 & $16 \%$ & 2.67 & 0.892 \\
\hline 15 & $\begin{array}{l}\text { I speak confidently in } \\
\text { front of the people }\end{array}$ & 17 & $27 \%$ & 24 & $38 \%$ & 19 & $30 \%$ & 4 & $6 \%$ & 2.16 & 0.895 \\
\hline 16 & $\begin{array}{l}\text { I use internet and } \\
\text { computers to study } \\
\text { and improve English }\end{array}$ & 0 & $0 \%$ & 8 & $13 \%$ & 23 & $36 \%$ & 33 & $52 \%$ & 3.39 & 0.704 \\
\hline 17 & $\begin{array}{l}\text { I find opportunities to } \\
\text { learn English outside } \\
\text { class }\end{array}$ & 6 & $9 \%$ & 19 & $30 \%$ & 24 & $38 \%$ & 15 & $23 \%$ & 2.75 & 0.926 \\
\hline 18 & $\begin{array}{l}\text { I make notes and } \\
\text { summaries of my } \\
\text { lessons }\end{array}$ & 10 & $16 \%$ & 29 & $45 \%$ & 12 & $19 \%$ & 13 & $20 \%$ & 2.44 & 0.990 \\
\hline 19 & $\begin{array}{l}\text { I practice English } \\
\text { outside the course } \\
\text { such as: record my } \\
\text { own voice; speak to } \\
\text { other people in } \\
\text { English }\end{array}$ & 7 & $11 \%$ & 28 & $44 \%$ & 14 & $22 \%$ & 15 & $23 \%$ & 2.58 & 0.973 \\
\hline 20 & $\begin{array}{l}\text { I use audio-visual } \\
\text { materials to practice } \\
\text { and develop my } \\
\text { speech }\end{array}$ & 8 & $13 \%$ & 8 & $13 \%$ & 22 & $34 \%$ & 26 & $41 \%$ & 3.03 & 1.023 \\
\hline 21 & $\begin{array}{l}\text { I attend different } \\
\text { seminars, training } \\
\text { courses, conferences } \\
\text { to improve my } \\
\text { English }\end{array}$ & 18 & $28 \%$ & 30 & $47 \%$ & 14 & $22 \%$ & 2 & $3 \%$ & 2.00 & 0.797 \\
\hline
\end{tabular}




\begin{tabular}{|c|c|c|c|c|c|c|c|c|c|c|c|}
\hline \multirow{2}{*}{ No. } & \multirow{2}{*}{ Statements } & \multicolumn{2}{|l|}{ SD } & \multicolumn{2}{|l|}{ D } & \multicolumn{2}{|l|}{$\mathbf{A}$} & \multicolumn{2}{|l|}{$\mathbf{S A}$} & \multirow{2}{*}{ Mean } & \multirow{2}{*}{ STD } \\
\hline & & TV & $\mathbf{P}$ & TV & $\mathbf{P}$ & TV & $\mathbf{P}$ & TV & $\mathbf{P}$ & & \\
\hline 22 & $\begin{array}{l}\text { I talk to the teachers } \\
\text { and friends outside } \\
\text { the course in English }\end{array}$ & 14 & $22 \%$ & 29 & $45 \%$ & 18 & $28 \%$ & 3 & $5 \%$ & 2.16 & 0.821 \\
\hline 23 & $\begin{array}{l}\text { Besides the contents } \\
\text { prescribed in the } \\
\text { course, I read extra } \\
\text { materials in advance }\end{array}$ & 11 & $17 \%$ & 32 & $50 \%$ & 19 & $30 \%$ & 2 & $3 \%$ & 2.19 & 0.753 \\
\hline 24 & $\begin{array}{l}\text { I change my learning } \\
\text { approach when I find } \\
\text { it inappropriate }\end{array}$ & 5 & $8 \%$ & 14 & $22 \%$ & 29 & $45 \%$ & 16 & $25 \%$ & 2.88 & 0.882 \\
\hline 25 & $\begin{array}{l}\text { I am aware of } \\
\text { whether my learning } \\
\text { approaches are } \\
\text { suitable to myself or } \\
\text { not }\end{array}$ & 3 & $5 \%$ & 16 & $25 \%$ & 32 & $50 \%$ & 13 & $20 \%$ & 2.86 & 0.794 \\
\hline 26 & $\begin{array}{l}\text { I find ways to } \\
\text { conquer those } \\
\text { affective factors that } \\
\text { might have negative } \\
\text { influence on my } \\
\text { English study }\end{array}$ & 2 & $3 \%$ & 24 & $38 \%$ & 30 & $47 \%$ & 8 & $13 \%$ & 2.69 & 0.732 \\
\hline 27 & $\begin{array}{lrr}\text { I try } & \text { to } & \text { take } \\
\text { advantage } & \text { of } & \text { the } \\
\text { learning } & \text { resources } \\
\text { available } & & \\
\end{array}$ & 1 & $2 \%$ & 11 & $17 \%$ & 42 & $66 \%$ & 10 & $16 \%$ & 2.95 & 0.628 \\
\hline 28 & $\begin{array}{l}\text { I try to use the new } \\
\text { knowledge when I } \\
\text { practice my English }\end{array}$ & 1 & $2 \%$ & 14 & $22 \%$ & 28 & $44 \%$ & 21 & $33 \%$ & 3.08 & 0.783 \\
\hline 29 & $\begin{array}{l}\text { I try to cooperate and } \\
\text { learn together with } \\
\text { my classmates }\end{array}$ & 2 & $3 \%$ & 20 & $31 \%$ & 28 & $44 \%$ & 14 & $22 \%$ & 2.84 & 0.801 \\
\hline 30 & $\begin{array}{lll}\text { I realize the learning } \\
\text { mistakes I've } & \text { made } \\
\text { during my } & \text { study } \\
\text { process } & & \\
\end{array}$ & 1 & $2 \%$ & 14 & $22 \%$ & 25 & $39 \%$ & 24 & $38 \%$ & 3.13 & 0.807 \\
\hline 31 & $\begin{array}{l}\text { I know the reasons } \\
\text { why I make mistakes } \\
\text { and will take actions } \\
\text { to correct them }\end{array}$ & 1 & $2 \%$ & 14 & $22 \%$ & 21 & $33 \%$ & 28 & $44 \%$ & 3.19 & 0.833 \\
\hline 32 & $\begin{array}{l}\text { I try to use } \\
\text { appropriate learning } \\
\text { approaches to make } \\
\text { myself a better } \\
\text { language learner }\end{array}$ & 2 & $3 \%$ & 10 & $16 \%$ & 30 & $47 \%$ & 22 & $34 \%$ & 3.13 & 0.787 \\
\hline 33 & $\begin{array}{l}\text { I note my strengths } \\
\text { and weaknesses in } \\
\text { learning English and } \\
\text { improve them }\end{array}$ & 3 & $5 \%$ & 24 & $38 \%$ & 19 & $30 \%$ & 18 & $28 \%$ & 2.81 & 0.906 \\
\hline 34 & $\begin{array}{l}\text { I evaluate my } \\
\text { learning approaches } \\
\text { in order to find the } \\
\text { problems of my study }\end{array}$ & 6 & $9 \%$ & 17 & $27 \%$ & 28 & $44 \%$ & 13 & $20 \%$ & 2.75 & 0.891 \\
\hline 35 & $\begin{array}{l}\text { I always take every } \\
\text { opportunity to speak } \\
\text { English. }\end{array}$ & 4 & $6 \%$ & 29 & $45 \%$ & 22 & $34 \%$ & 8 & $13 \%$ & 2.50 & 0.800 \\
\hline
\end{tabular}


Most of the learners admitted that they seldom attended events such as seminars, training courses, and international conferences. They felt uninteresting with the events and it would get boring. However, they claimed that they actively learned English beyond the class such as using the internet to watch the movie, listen to the music and others. In other words, they liked learning English with media. It is in line with Bajrami and Ismaili (2016) who claim the use of authentic materials such as video and audio materials can be used as a motivational tool in learning English. Authentic materials such as video materials also can be suggested to be used in the classrooms. The wellchosen material can be suggested to create a positive classroom atmosphere. It means that appropriate material can improve students' language motivation to learn the target language and it will be affected to students' learning outcomes.

Learner 1: "[...] I always learn through media such as movie, song lyrics, CNN news, and many more. It works for me to improve my English skill. After got new vocabularies, I usually use it in my daily life, I use those vocabularies to practice with my friends."

Learner 2: "If my teacher did not ask me to attend the seminars or conferences, I would not attend it. But I practice my English in other ways such as watching YouTube or playing games. It will not be boring rather than attending the conferences. I can say the internet and computers are the things that help me so much in learning English."

Learner 3: "[...] It depends on who the speakers are and what they will talk about. I will skip it if it is not interesting for me. I am a visual and auditory learner. When I am listening to music or watching movies, I like taking not of unfamiliar vocabulary, then I find out the meaning of it in the dictionary. I write the sentences using those words and I use those words when I speak with my friends."

Learner 4: "If most of my classmates attend the events, I will follow them. I have ever attended the seminars and took notes about important information from the speakers. I actually prefer watching movies with English subtitles, it truly helps me to enrich my vocabularies."

Learner 5: "Attending the seminars sometimes would get bored. If it is not obligatory, I will not attend it. But I know good information will be got from those events. It would be nice if the speakers talk about current issues in the world."

In terms of self-effort, all the respondents had their own ways to learn English autonomously. As stated above, most of them learn English through media and the internet. In addition, they also did self-monitoring and evaluation when learning English. They claimed it would be useful to improve their knowledge if they monitored and evaluated their learning process. Monitoring and Evaluation in the learning process are crucial in attaining the target language. A lot of advantages are derived in doing selfmonitoring and evaluation such as it can help students to determine and reach their target language and increase their awareness and focus during learning activities (Chang, 2010).

Learner 3: "As I said before, I am a visual and auditory learner, I will use appropriate learning approaches to make myself a better language learner. I also evaluate my learning approaches to find the problems of my study. I do of course it with my teacher's help.

Learner 4: "I will change my learning approach if it is not appropriate. I am responsible with my own study objectives because I obviously know my strengths and weaknesses in learning English. when I got a "not perfect" score, I will evaluate it by myself or ask to my teacher the correct answer." 
Learner 5: “[...] learning process at school sometimes is not appropriate with my learning styles. I will use my own strategies to understand some materials. When I realize the learning mistakes I've made during my study process, I directly evaluate my study."

\section{CONCLUSION AND SUGGESTION}

After a thorough data analysis obtained from the questionnaire and interview, it can be concluded that although some constraints were reported, more positive responses were still shown by the learners. They positively disposed to learner autonomy in theory, and most of them familiar with the notion of learner autonomy. It can be seen from the result of their understanding of instructors' teaching objectives and requirements, setting up their objectives and study plans, and find out learners' practices in learning English autonomously.

The findings above highlight the students should take advantages of learning English. They can learn from available sources in the class and beyond the classroom. It will strongly encourage learners to be more autonomous. The teacher-student relationship is crucial as well. The teacher's guidance makes students feel more aware and secure in classroom activities. It also infers learners' goals and objective so that helps them achieve good outcomes in the learning process.

Based on the research result, several suggestions are offered for the readers and stakeholders. First, the teacher may pay attention to classroom activities. The more interesting classroom activities provided by the teacher, the more enthusiastic learners involve in EFL classrooms. Second, although learners are able to choose and adapt the English materials, teachers' roles are still essential to guiding the learners find out their appropriate strategies in learning English. Furthermore, the research was conducted in a private university with limited participants. Further researchers, thus, need to conduct the research in various universities with a large number to obtain a deeper and wider understanding about learners perceive in autonomous language learning.

\section{REFERENCES}

Ahmadzadeh, R., Zabardast, S. (2014). Learner autonomy in practice. International Journal on New Trends in Education and Their Implications, 49-57.

Amirian, S. M. (2017). An investigation into Iranian EFL teachers' perception of learner autonomy. Journal of Language Teaching and Research, 807-816.

Ary, D., Jacobs, L. C., Sorensen, C., \& Razavieh, A. (2010). Introduction to Research in Education (8th ed.). Wadsworth.

Bajrami, L., \& Ismaili, M. (2016). The Role of Video Materials in EFL Classrooms. Procedia - Social and Behavioral Sciences, 232(April), 502-506. https://doi.org/10.1016/j.sbspro.2016.10.068

Benson, P. (2008). Teachers' and learners'perspectives on autonomy. In T. Lamb \& H. Reinders (Eds)., Learner and Teacher Autonomy: Concepts, Realities, and Responses. John Benjamins. 
Boyce, A. (2010). The effectiveness of increasing language learning strategy awareness for students studying English as a second language Alan Boyce A thesis submitted to Auckland University of Technology in partial fulfilment of the degree of Master of Education School of.

Chang, M.-M. (2010). Effects of Self-Monitoring on Web-Based Language Learner 's Performance and Motivation. 27(2), 298-310.

Creswell, J. (2012). Design: Choosing Among Five Approaches. In Design: Choosing Among Five Approaches (Vol. 3, Issue June).

DeMarrais, K. (2004). Qualitative interview studies: Learning through experience. Foundations for Research. Methods of Inquiry in Education and the Social Sciences. 51-68.

Genç, G. (2015). Autonomous Learning Capacity of Efl Student Teachers. International Journal of Languages' Education, 1(Volume 6), 23-23. https://doi.org/10.18298/ijlet.483

Green, P., Skinner, D. (2005). Does time management training work: an evaluation. International Journal of Training and Development, 9, 124-139.

Joshi, K. R. (1970). Learner Perceptions and Teacher Beliefs about Learner Autonomy in Language Learning. Journal of NELTA, 16(1-2), 12-29. https://doi.org/10.3126/nelta.v16i1-2.6126

Kemala, Z. (2016). An Analysis of Factors Influencing the Autonomous Learners in Learning English. Eltin, 4(I), 11-20.

Kumbakonam, U. R., Archana, S., \& Rani, \& K. U. (2017). Role of a Teacher in English Language Teaching (Elt). International Journal of Educational Science and Research, 7(1), 1-4. www.tjprc.org

Le, Q. X. (2013). Fostering learner autonomy in language learning in tertiary education: an intervention study of university students in hochiminh city, vietnam. PQDT $U K \&$ Ireland.

Lengkanawati, N. S. (2017). Learner autonomy in the Indonesian EFL settings. Indonesian Journal of Applied Linguistics, 6(2), 222-231.

Malik, R. S., \& Hamied, F. A. (2014). Research Methods: A Guide For First Time Researcher. UPI Press.

Mardjuki, M. S. (2018). Learner Autonomy: Gender-Based Perception Among EFL Indonesian Students. Indonesian Journal of EFL and Linguistics, 3(1), 1. https://doi.org/10.21462/ijefll.v3i1.46

Mısır, H., Koç, D. K., \& Koç, S. E. (2018). An analysis of learner autonomy and autonomous learning practices in massive open online language courses. Arab World English Journal(4), 24-39.

Salimi, A., \& Ansari, N. (2015). Learner autonomy: Investigating Iranian English teachers' beliefs. Theory and Practice in Language Studies, 1106-1115.

Samperio Sanchez, N. (2017). Discovering Students' Preference for Classroom Activities and Teachers' Frequency of Activity Use. Colombian Applied Linguistics Journal, 19(1), 51. https://doi.org/10.14483/calj.v19n1.9292 
Vieira, F. (2007). Teacher autonomy: Why should we care. Independence, 42, 20-48.

Zhenhui, R. (2002). Chinese students' perceptions of communicative and noncommunicative activities in EFL classroom. System, 30(30), 85-105. 